Indonesian Journal of Biotechnology, June, 2014

Vol. 19, No. 1, pp.1-11

\title{
Inter- and intraspecific variation of chloroplast mini- and microsatellites DNA in the four closed related Acacia species
}

\author{
AYPBC Widyatmoko ${ }^{1^{*}}$ and Susumu Shiraishi ${ }^{2}$
}

${ }^{1}$ Center for Forest Biotechonology and Tree Improvement, Yogyakarta

${ }^{2}$ Faculty of Agriculture, Kyushu University, Fukuoka, Japan

\begin{abstract}
Mini- and microsatellites of four Acacia species, A. aulacocarpa, A. auriculiformis, A. crassicarpa and A. mangium were investigated on four non-coding regions of cpDNA, the intron of $\operatorname{trn} \mathrm{L}$, and the intergenic spacers of $\operatorname{trn} \mathrm{L}-\operatorname{trn} \mathrm{P}, \operatorname{trn} \mathrm{D}-\operatorname{trn} \mathrm{Y}$, and $\operatorname{trn} \mathrm{P}-\operatorname{trn} \mathrm{W}$. Nine single base substitutions and six informative miniand microsatellites were detected in the the four cpDNA non-coding regions. Based on the substitutions and mini- and microsatellites, ten cpDNA haplotypes (A - J) could be distinguished. Acacia auriculiformis possessed five haplotypes, A. aulacocarpa, four haplotypes, and A. crassicarpa, three haplotypes. All samples of A. mangium possessed the same haplotype. Mini- and microsatellites recognized in this study can be used for species identification of the four Acacia species. The ten haplotypes could divided the four species into 2 groups, A. aulacocarpa-A.crassicarpa group and A. auriculiformis-A. mangium group. By developing the PCR-based markers based on the sequence information, many experiments can be carried out for the Acacia improvement programs.
\end{abstract}

Keywords: Acacia, microsatellite, variation, chloroplast DNA

\section{Introduction}

For this decade, microsatellite, also called simple sequence repeats (SSRs), has become a popular tool for investigating genetic variations (Filizi and Koc, 2012), genetic map (Butcher and Moran, 2000), and paternity diagnosis (Cato and Richardson, 1996). This popularity stems from its high informativeness, the codominance of alleles, unequivocalness and abundance in the genomes of almost all eukaryotes. SSR markers are assayed using polymerase chain reaction (PCR), which means that genotype data of numerous loci can be obtained relative quickly from small quantity of plant tissue.

Recently, genetic markers derived from organelle genomes are employed because of their simple and uniparental

*Corresponding author:

AYPC Widyatmoko

Center for Forest Biotechonology and Tree

Improvement, Yogyakarta

E-mail: aviwicaksono@yahoo.com modes of inheritance. This makes organelle markers inevitable for population genetic and phylogenetical studies. Genetic markers based upon simple sequence repeats in chloroplast genomes (cpSSRs) have been shown to be high useful markers for the study of germplasm analysis in several plant species, such as Solanaceous (Bryan et al., 1999), pine (Powell et al., 1995), soybean (Xu et al., 2002) and Olea (Filizi and Koc, 2012). Since chloroplast DNA (cpDNA) shows uniparental inheritance, cpDNA markers are used for the seed orchard management of Douglas-fir (Stoehr et al., 1998), lodgepole pine (Stoehr and Newton, 2002) and Pinus pinaster (Fernandes et al., 2008). Chloroplast SSRs are analogous to those in the nuclear genome, except that they are characteristically composed of mononucleotide repeats rather than di-, tri- or tetra-nucleotide repeats. Owing to the haploid nature and large numbers of the chloroplast genome copies, these markers 
are particularly easy to be analyzed by using PCR and electrophoresis.

Non-coding region has been used for elucidating phylogenetic relationship of different taxa (Olmstead and Palmer, 1994) and sequence variation (Ohsako and Ohnishi, 2000; Fujii et al., 1997, 1999; DumolinLapègue et al., 1997). Compared with coding regions, non-coding regions may provide more informative characters in phylogenetic studies at species level because of their high variability due to the lack of functional constrains. Provan et al. (1996) and Bryan et al. (1999) found more cPSSR markers in non-coding regions compared with coding regions.

Acacia (Mimosoidea) has been introduced as multiple-purpose species for plantation in tropical and subtropical areas around the world, and becomes one of the most important species for a pulp production. Balodis and Clark (1988) reported that by the year 2000, tropical Acacia plantations in Southeast Asia and China might be more than one million hectares. Genus Acacia is a large genus of woody plant (more than 1200 species), and is occurring naturally in all continents except for Eurasia. About 650 species occur in Australia. Acacia mangium is one of the most important Australian Acacia species and has the largest plantations compared with the other Acacia species. Since a very low genetic variation has been reported for A. mangium (Moran et al., 1989a; Khasa et al., 1993, 1994), it is necessary to introduce other Acacia species especially for breeding program of Acacia. The genetic diversity of $A$. mangium has also been studied using RFLP (restriction fragment length polymorphism) markers (Butcher et al., 1998). Acacia aulacocarpa, A. auriculiformis, and $A$. crassicarpa are other important Acacia species that have a close relationship with $A$. mangium, and show a good property for pulp and paper production.

Aside from molecular data, there is few current knowledge of the phylogenetic relationship and genetic variation of the four Acacia species. Investigation of genetic variations and relationship of the four species were reported by Widyatmoko and Shiraishi (2010). Based on RAPD and SSCP analysis, the four species were grouped into two major strains, $A$. aulacocarpa - $A$. crassicarpa and A. auriculiformis - A. mangium groups. This result was also supported by the data of nucleotide sequencing of four cpDNA genes (Widyatmoko and Shiraishi, 2011). No sequence variation was found between the two species in the latter group. Among them, A. aulacocarpa possessed the highest genetic variation compared with the other three species. A very low genetic variability was revealed in A. mangium. Although interspecific relationship of these species has been clarified in previous study (Widyatmoko and Shiraishi, 2010 and 2011), the details on their intra- and interspecific relationships still are unsolved.

In the present study, we investigated mini- and microsatellites on four non-coding regions of cpDNA, the intron of $\operatorname{trn} \mathrm{L}$, and the intergenic spacers of $\operatorname{trn} \mathrm{L}-\operatorname{trn} \mathrm{P}, \operatorname{trn} \mathrm{D}-\operatorname{trn} \mathrm{Y}$, and $\operatorname{trn} \mathrm{P}-\operatorname{trn} \mathrm{W}$. The variation of mini- and microsatellite sequences in the four noncoding cpDNA regions, which provides sufficient information to clarify the intraand interspecific variation of the four Acacia species, are described in this study.

\section{Materials and methods}

Seeds from different seed lots, which represent the natural distribution of each species, were used in order to investigate mini- and microsatellite variations of the four Acacia species (Figure 1). All the materials used in this study were obtained from the Australian Tree Seed Centre of CSIRO (Commonwealth Scientific and Industrial Research Organization), Australia and Research and Development Center for Biotechnology and Forest Tree Improvement, Indonesia. The detail of the materials is shown in Table 1.

Total genomic DNA was extracted from the seeds with a mortar and pestle by 


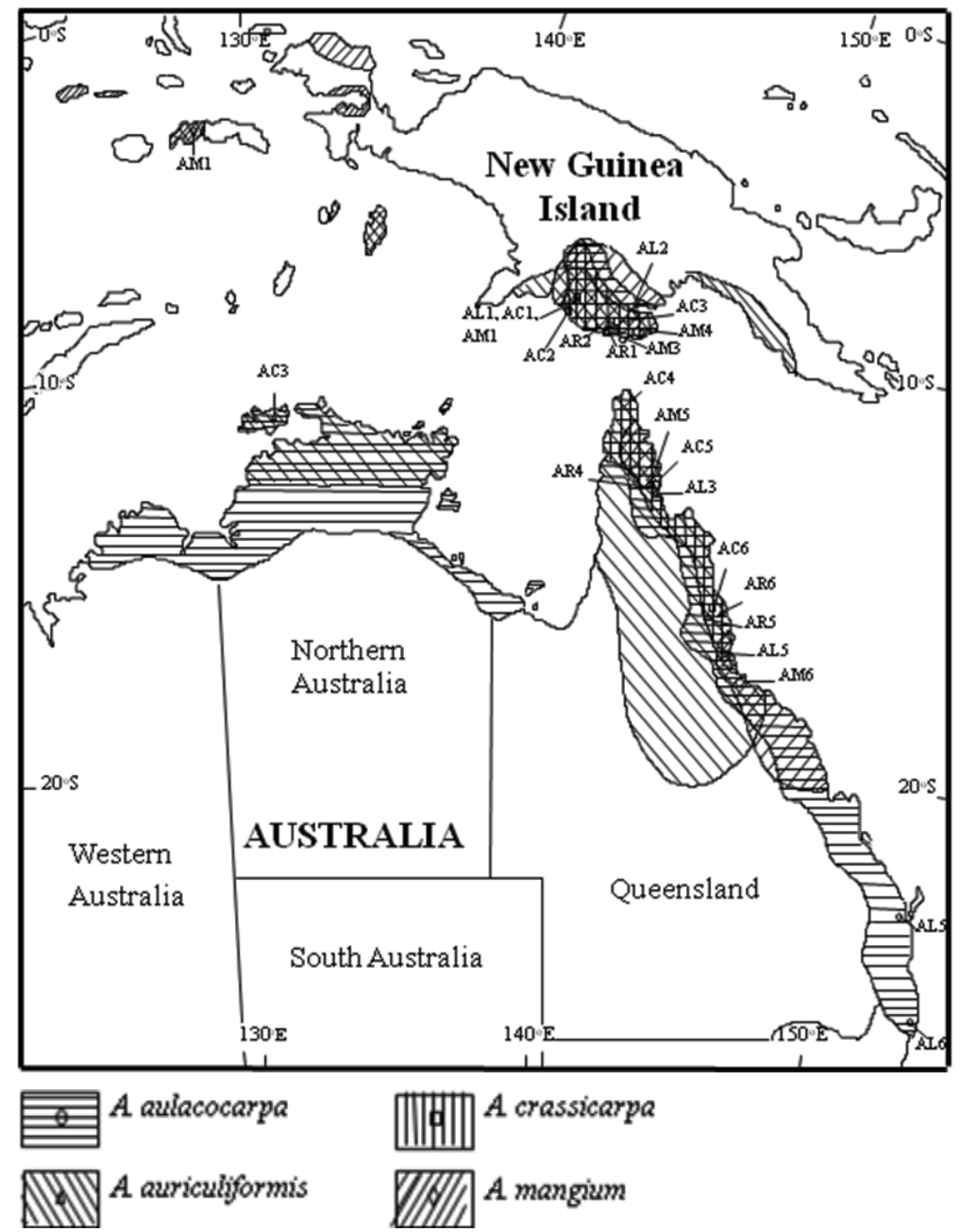

Figure 1. Samples used in this study and the natural distribution of the four Acacia species.

an SDS isolation method. Each seed was ground using $400 \mu \mathrm{l}$ SDS extraction buffer, which contained $50 \mathrm{mM}$ Tris- $\mathrm{HCl}(\mathrm{pH} 9.0)$, $1 \%(\mathrm{w} / \mathrm{v})$ SDS, $10 \mathrm{mM}$ EDTA, and $0.5 \%(\mathrm{v} / \mathrm{v})$ 2-Mercaptoethanol. After incubation at $65^{\circ} \mathrm{C}$ for $60 \mathrm{~min}, 200 \mu \mathrm{l}$ of $7.5 \mathrm{M}$ ammonium acetate was added. The solution was kept on ice for $30 \mathrm{~min}$, and was then centrifuged at $0^{\circ} \mathrm{C}$ at $15,000 \mathrm{rpm}$ for $40 \mathrm{~min}$. The sample in the aqueous phase $(400 \mu \mathrm{l})$, was transferred to a new tube, and the DNA was precipitated by the addition of $400 \mu \mathrm{l}$ isopropanol. After circa $10 \mathrm{~min}$, the precipitate was collected by centrifugation at $15,000 \mathrm{rpm}$ for $10 \mathrm{~min}$. The supernatant was completely removed, and the pellet was washed twice with $1.0 \mathrm{ml}$ of $70 \%$ Ethanol. After the pellet was washed using a vacuum evaporator for $2 \mathrm{~min}$, it was resuspended in $100 \mu \mathrm{l}$ purified $\mathrm{H}_{2} \mathrm{O}$. The crude DNA was purified with GENECLEAN III (BIO 101), and the purified DNA was utilized as a template for PCR.

For PCR amplification of the four noncoding cpDNA regions (the trn $\mathrm{L}$ intron, the intergenic spacer between $\operatorname{trn} \mathrm{L}-\operatorname{trn} \mathrm{P}, \operatorname{trn} \mathrm{D}$ - trn $\mathrm{Y}$, and $\operatorname{trn} \mathrm{P}$ - trn $\mathrm{W})$, four primer pairs described in Watanabe et al. (1997) were used. PCR was performed in a total volume of $20 \mu \mathrm{l}$ containing $4 \mathrm{ng}$ of genomic DNA, $0.25 \mu \mathrm{M}$ of each primer, $10 \mathrm{mM}$ Tris- $\mathrm{HCl}(\mathrm{pH} 8.3), 50 \mathrm{mM}$ $\mathrm{KCl}, 3.0 \mathrm{mM} \mathrm{MgCl}_{2}, 200 \mathrm{mM}$ of each dNTP, and 0.25 unit/10 $\mu 1$ Ex Taq DNA polymerase. 
Widyatmoko and Shiraishi

I.J. Biotech.

Table 1. Details of samples of the four Acacia species

\begin{tabular}{|c|c|c|c|}
\hline Species & No. & Seed source & Seedlot No. \\
\hline \multirow[t]{6}{*}{ Acacia aulacocarpa A. Cunn. ex Benth. } & AL1 & Kuel, Irian Jaya NGI & AL-1001** \\
\hline & AL2 & Makapa WP NGI & 16947-M 0000003 \\
\hline & AL3 & Old Rock Hart Airstrip QLD & 18358-GJM 1377 \\
\hline & AL4 & 10K NW. Mt. Molloy QLD & 17905-TREE 1 \\
\hline & AL5 & 3K S Mt. Larcom QLD & 17739-GB 000022 \\
\hline & AL6 & Samford QLD & 17891-GB 000096 \\
\hline \multirow[t]{6}{*}{ Acacia auriculiformis Cunn. ex Benth. } & AR1 & Morehead R Rouku WP NGI & 16606-BVG 01220 \\
\hline & AR2 & Bensbach WP NGI & 17553-KN 000011 \\
\hline & AR3 & (R) Orchard Melville INT NT & $18601-6$ \\
\hline & AR4 & Lower Poscoe River QLD & 18359-MHL 20 \\
\hline & AR5 & Boggy Creek QLD & 17966-BН 14061 \\
\hline & AR6 & E Normamby River QLD & 16756-BG 004936 \\
\hline \multirow[t]{6}{*}{ Acacia crassicarpa Cunn. ex Benth. } & $\mathrm{AC} 1$ & Kuel, Irian Jaya NGI & AC $-1107^{* *}$ \\
\hline & $\mathrm{AC} 2$ & Wasur, Irian Jaya NGI & AC-1001** \\
\hline & AC3 & Gubam Village WP NGI & 16597-BCG 01100 \\
\hline & $\mathrm{AC} 4$ & Jardine River-Bamaga. QLD & 16128-JM 001440 \\
\hline & AC5 & Claudie River QLD & 17944-MHL 04 \\
\hline & AC6 & Parich of Annan QLD & 16775-ВН 013582 \\
\hline \multirow[t]{6}{*}{ Acacia mangium Willd. } & AM1 & Piru, Seram Seram & $570^{*}$ \\
\hline & AM2 & Kuel, Irian Jaya NGI & AM- $1001^{* *}$ \\
\hline & AM3 & Gubam Ne Morehead WP NGI & 16991-BVG 01574 \\
\hline & AM4 & Wipim District WP NGI & 16971-BG 01626 \\
\hline & AM5 & Claudie River QLD & 17946-GJM 1110 \\
\hline & AM6 & Tully-Mission Beach QLD & 17703-GLM 00920 \\
\hline
\end{tabular}

* The seedlots were collected by Forest Tree Improvement Research and Development Institute, Yogyakarta, Indonesia (*: bulk seedlot; **: individual seedlot)

The other seedlots were collected by Australia Tree Seed Centre, CSIRO, Australia

NGI: New Guinea Island; QLD: Queensland; NT: Northern Terrritory

DNA amplification was performed with a Gene Amp PCR System Model 9600 (PerkinElmer) programmed as follows: $95^{\circ} \mathrm{C}$ for $90 \mathrm{~s}$, 30 cycles of $30 \mathrm{~s}$ at $94^{\circ} \mathrm{C}, 30 \mathrm{~s}$ at $55^{\circ} \mathrm{C}$, and 90 $\mathrm{s}$ at $72^{\circ} \mathrm{C}$, followed by $60 \mathrm{~s}$ at $72^{\circ} \mathrm{C}$. The PCR product was separated by electrophoresis in $1.5 \%$ agarose gel and the target fractions were excised from the gel. DNA was recovered from the gel particles and was purified using QIAEX II Gel Extraction (QIAGEN). The sequence reaction was carried out using a Thermo Sequenase fluorescent labeled primer cycle sequencing kit (Amersham Pharmacia Biotech), the template DNA, and -21M13 (TGTAAAACGACGGCCAGT) / M13Rev (CAGGAAACAGCTATGA-CC) sequence primer 5'-labeled with Texas Red fluorescent dye (Amersham Pharmacia
Biotech). The sequence was analyzed with a Hitachi SQ5500 DNA Sequencer.

\section{Results}

Sequence variations in the four chloroplast non-coding regions

Length polymorphisms were revealed in the four chloroplast non-coding regions (Tables 2 and 3). For the four Acacia species, the length of the trn $\mathrm{L}$ intron ranged from 578 up to 596 bps. This region was the highest length polymorphic compared with the other regions. The lengths of the $\operatorname{trn} \mathrm{L}-\operatorname{trn} \mathrm{F}$, trn $\mathrm{D}-\operatorname{trn} \mathrm{Y}$, and $\operatorname{trn} \mathrm{P}-\operatorname{trn} \mathrm{W}$ spacer regions were 456 - 459, 530 - 531, and 275 - 280 bps, respectively (Table 3 ). The length variations of the regions were caused by SSRs and indels (insert/deletion). Compared with another 


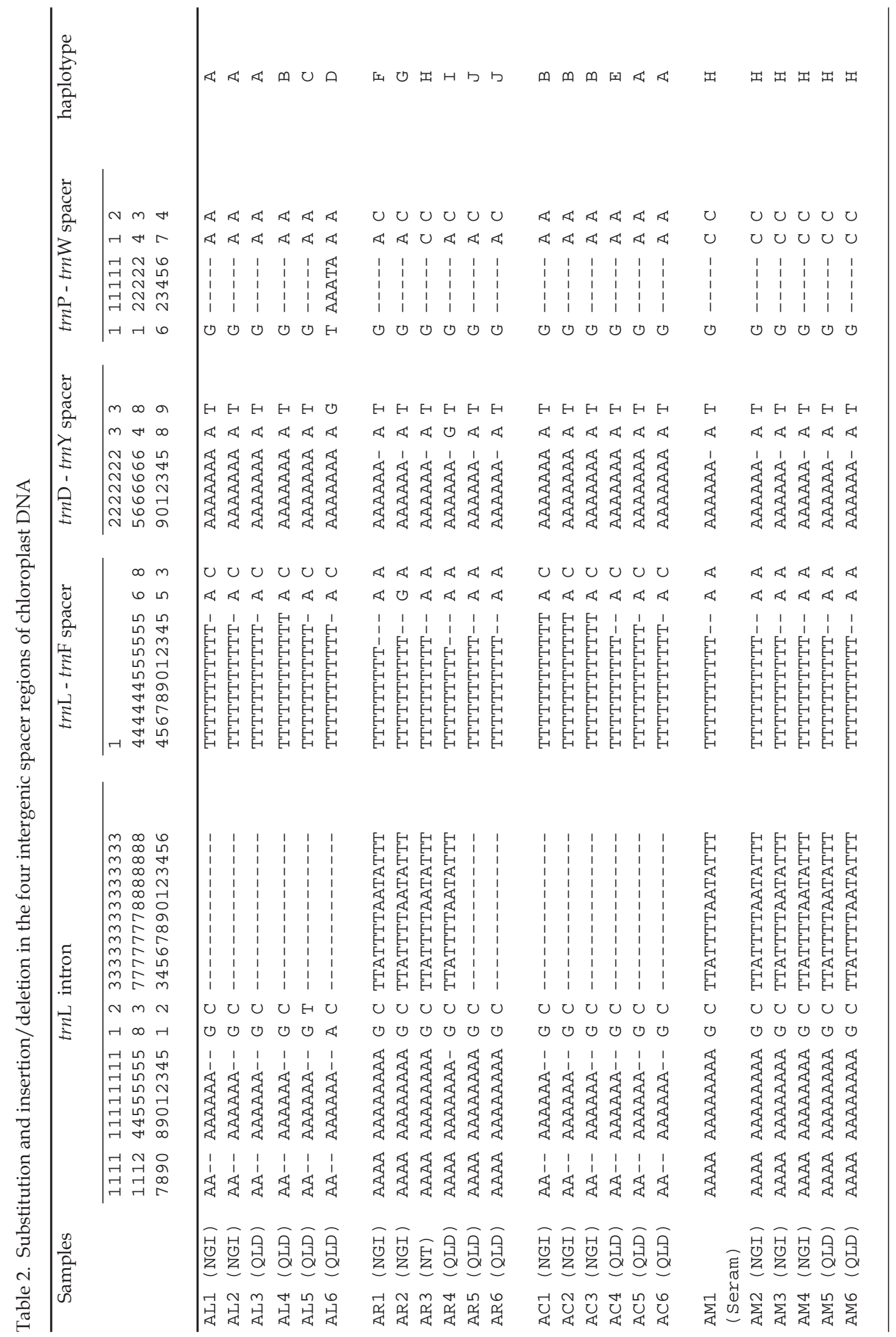


Table 3. Number of substitution and insertion/deletion within the four Acacia species in four intergenic spacer regions of chloroplast DNA

\begin{tabular}{|c|c|c|c|c|c|c|c|c|c|c|c|}
\hline \multirow{3}{*}{ Region } & \multirow{3}{*}{ Length } & \multicolumn{5}{|c|}{ Number of substitution } & \multicolumn{5}{|c|}{ Number of insertion/deletion* } \\
\hline & & \multirow{2}{*}{$\begin{array}{l}\text { among } \\
\text { species }\end{array}$} & \multicolumn{4}{|c|}{ within species } & \multirow{2}{*}{$\begin{array}{l}\text { among } \\
\text { species }\end{array}$} & \multicolumn{4}{|c|}{ within species } \\
\hline & & & $\mathrm{AL}$ & AR & $\mathrm{AC}$ & $\mathrm{AM}$ & & $\mathrm{AL}$ & $\mathrm{AR}$ & $\mathrm{AC}$ & $\mathrm{AM}$ \\
\hline trnL intron & $578-596$ & 2 & 2 & 0 & 0 & 0 & 5 & 0 & 2 & 0 & 0 \\
\hline $\operatorname{trn} \mathrm{L}-\operatorname{trn} \mathrm{F}$ & $456-459$ & 2 & 0 & 1 & 0 & 0 & 3 & 1 & 1 & 2 & 0 \\
\hline $\operatorname{trn} \mathrm{D}-\operatorname{trn} \mathrm{Y}$ & $530-531$ & 2 & 1 & 1 & 0 & 0 & 1 & 0 & 0 & 0 & 0 \\
\hline $\operatorname{trn} \mathrm{P}-\operatorname{trn} \mathrm{W}$ & $275-280$ & 3 & 1 & 1 & 0 & 0 & 1 & 1 & 0 & 0 & 0 \\
\hline Total & & 9 & 4 & 3 & 0 & 0 & 10 & 2 & 3 & 2 & 0 \\
\hline
\end{tabular}

* The number of insertion/deletion for simple sequence repeat (SSR), 1 base is counted as 1 indel (see Table 2 for details) AL: A. aulacocarpa; AR: A. auriculiformis; AC: A. crassicarpa; AM: A. mangium

Acacia sp. (Murphy et al., 2000), the lengths of the trn L intron and the $t r n \mathrm{~L}-\operatorname{trn} \mathrm{F}$ spacer regions of the four Acacia species used in this study were longer. These spacer regions were also longer than those in soybean (Xu et al., 2000).

\section{Intra- and interspecies variations among the four Acacia species}

Nine single base substitutions were detected in the four cpDNA noncoding regions (Tables 2 and 3 ). These substitutions included four transitions and five transversions. A numerous numbers of transversions were also detected in soybean chloroplast genome (Xu et al., 2000).

Of the nine substitutions detected in the four non-coding regions, two substitutions detected in the trn D-trn $\mathrm{Y}$ and $t r n \mathrm{P}-\operatorname{trn} \mathrm{W}$ were interspesific, and were $\mathrm{A} / \mathrm{C}$ transversions (Table 3$)$. In the transversion at the $183^{\text {rd }}$ position of the $t r n \mathrm{~L}-\operatorname{trn} \mathrm{F}$ spacer region, $A$. aulacocarpa and $A$. crassicarpa showed C-base, and $A$. auriculiformis and $A$. mangium, A-base. Also at the $234^{\text {th }}$ position of the trnP - trnW, A. aulacocarpa and $A$. crassicarpa, showed A-base, and $A$. auriculiformis and $A$. mangium, C-base. Based on these substitutions, A. aulacocarpa and $A$. crassicarpa could be distinguished from $A$. auriculiformis and A. mangium.

As intraspecific variations, seven substitutions were revealed in the four noncoding regions, and they were recognized only in A. aulacocarpa and A. auriculiformis. No intraspesific substitutions were in $A$. crassicarpa and A. mangium (Table 3 ). In the trn L intron, only $A$. aulacocarpa possessed variations within species. Otherwise, in the $\operatorname{trn} \mathrm{L}$ - trnF, only A. auriculiformis showed an intraspecific variation. In the $\operatorname{trn} \mathrm{D}-\operatorname{trn} \mathrm{Y}$ and $t r n \mathrm{P}-t r n \mathrm{~W}$ regions, A. aulacocarpa and A. auriculiformis showed within-species polymorphisms.

Six informative mini-and microsatellites were detected in the four non-coding regions (Table 2 ). In the $t r n \mathrm{~L}$ intron, two single-base SSRs of A and a 14-base repeat (TTATTTTAATATTT) were detected. In the $\operatorname{trn} \mathrm{L}-\operatorname{trn} \mathrm{F}$ and the $\operatorname{trn} \mathrm{D}-\operatorname{trn} \mathrm{Y}$, one single-base SSR of T and A was detected, respectively. In $\operatorname{trn} \mathrm{P}-\operatorname{trn} \mathrm{W}$, a 5-base repeat (AAATA) was detected. Three of the four single-base SSRs revealed in this study can be used for distinguishing species. Two SSRs were detected in the trnL intron, and one SSR was found in the trnD - trnY. A single-base repeat that consisted of two to four A-bases was detected at the $117-120^{\text {th }}$ position of the $t r n \mathrm{~L}$ intron region. Acacia aulacocarpa and $A$. crassicarpa showed two A-bases. On the other hand, A. auriculiformis and $A$. mangium showed four A-bases. Also at $148-155^{\text {th }}$ position, another A-repeat SSR was revealed. A. aulacocarpa and A. crassicarpa showed six A-bases, and $A$. mangium, eight A-bases. Five samples of $A$. auriculiformis showed eight A-bases, and only one sample showed seven A-bases. In the trnD - trn $\mathrm{Y}$, an informative A-repeat was detected at the $259-265^{\text {th }}$ position. A. aulacocarpa and 
Widyatmoko and Shiraishi

I.J. Biotech.

Table 4. Number of cpDNA haplotype in the four Acacia sp

\begin{tabular}{|c|c|c|c|c|c|c|c|c|c|c|c|}
\hline \multirow[t]{2}{*}{ Species } & \multirow{2}{*}{$\begin{array}{l}\text { Number of } \\
\text { haplotype }\end{array}$} & \multicolumn{10}{|c|}{ Haplotype frequencies* } \\
\hline & & A & B & $\mathrm{C}$ & $\mathrm{D}$ & $\mathrm{E}$ & $\mathrm{F}$ & $\mathrm{G}$ & $\mathrm{H}$ & I & $\mathrm{J}$ \\
\hline A. aulacocarpa & 4 & 3 & 1 & 1 & 1 & 0 & 0 & 0 & 0 & 0 & 0 \\
\hline A. auriculiformis & 5 & 0 & 0 & 0 & 0 & 0 & 1 & 1 & 1 & 1 & 2 \\
\hline A. crassicarpa & 3 & 2 & 3 & 0 & 0 & 1 & 0 & 0 & 0 & 0 & 0 \\
\hline A. mangium & 1 & 0 & 0 & 0 & 0 & 0 & 0 & 0 & 6 & 0 & 0 \\
\hline Total & & 5 & 4 & 1 & 1 & 1 & 1 & 1 & 7 & 1 & 2 \\
\hline
\end{tabular}

* See Table 2 for details of sequences of each haplotype

A. crassicarpa showed six A-bases, and $A$. auriculiformis and A. mangium showed seven A-bases. Based on these single-base SSRs, the four Acacia species could be grouped into two strains, A. aulacocarpa - A. crassicarpa and $A$. auriculiformis - $A$. mangium. This supports the result mentioned in Widyatmoko and Shiraishi (2010).

Of these threeSSRs and one minisatellite recognized in the four Acacia species, a variation within species was detected only in the $\operatorname{trn} \mathrm{L}$ intron $\left(148-155^{\text {th }}\right.$ position) of A. auriculiformis (Tables 2). In addition to the intraspecific variation, SSR variation of the $\operatorname{trn} \mathrm{P}-\operatorname{trn} \mathrm{W}\left(122^{\text {nd }}-126^{\text {th }}\right.$ position $)$ was detected only in A. aulacocarpa. Moreover, a single-base repeat of $\mathrm{T}$ appeared in the $\operatorname{trn} \mathrm{L}$ - trn $\mathrm{F}\left(44-55^{\text {th }}\right.$ position) was polymorphic in the three Acacia species except for A. mangium. Acacia aulacocarpa and $A$. auriculiformis included two variations, and A. crassicarpa, three variations at this position.

\section{Distribution of cpDNA haplotypes}

Ten cpDNA haplotypes (A - J) could be distinguished based on base substitutions and mini- and microsatellites detected in the four non-coding regions of cpDNA (Table 4). Acacia auriculiformis possessed five haplotypes (haplotypes F - J), A. aulacocarpa, four haplotypes (haplotypes A - D), and A. crassicarpa, three haplotypes (haplotypes A, B and E), respectively. All samples of A. mangium possessed the same haplotype (haplotype H).

Of the ten cpDNA haplotypes, five haplotypes were recognized in A. aulacocarpa and $A$. crassicarpa, while, remaining five haplotypes in $A$. auriculiformis and $A$. mangium. Of three haplotypes detected in A. crassicarpa, two haplotypes except for haplotype E were recognized also in $A$. aulacocarpa. The haplotype appeared in $A$. mangium was also detected in one sample of Northern Territory (NT) in A. auriculiformis. In this study, six samples of $A$. aulacocarpa can be separated into three groups, New Guinea Island (NGI) (haplotype A), North Queensland (NQ) (haplotypes A and B), and South Queensland (SQ) (haplotypes C and D). For A. crassicarpa, NGI and Queensland (QLD) samples showed different haplotypes: haplotype B for NGI, and haplotypes A and E for QLD. Geographical variations of cpDNA haplotypes were also revealed in A. auriculiformis. Six samples from three different areas showed regionally specific haplotypes, haplotypes F and G for NGI, haplotype $\mathrm{H}$ for NT, and haplotypes I and J for QLD.

\section{Discussion}

Variations of the four non-coding regions of cpDNA in the four Acacia species

In this study, inter- and intraspecific polymorphism was shown in the four non-coding regions of cpDNA. These polymorphisms were higher than those in the four genes of chloroplast genome (Widyatmoko and Shiraishi, 2011). In the four chloroplast genes, a sole polymorphism between the two groups ( $(A$. aulacocarpa $-A$. crassicarpa (group I) and A. auriculiformis - $A$. mangium (group II)) was revealed, and no 
polymorphism was recognized between the species of the same group. The sequence of the non-coding regions of cpDNA demonstrated that group I was distinguished from group II. There were two A/C substitutions and two indels between the two groups. Xu et al. (2000) distinguished three types of soybean based on sequences of non-coding regions of cpDNA. These results suggested that two Acacia species that belong to the same group were closely related.

In the three species except for $A$. mangium, intraspecific polymorphisms were detected in the four non-coding regions. Of the four Acacia species, only A. mangium showed no polymorphism in the six regions. Acacia aulacocarpa and $A$. auriculiformis showed intraspecific polymorphism. Otherwise, $A$. crassicarpa showed polymorphism only in the intergenic spacer region between $\operatorname{trn} \mathrm{L}$ $t r n \mathrm{~F}$. This supports the result in Widyatmoko and Shiraishi (2010) that A. aulacocarpa and $A$. auriculiformis possessed higher genetic variation compared with the other two species.

\section{Mini- and microsatellites of cpDNA in the four Acacia species}

Recently, there has been reported the presence of minisatellite sequence of chloroplast genome in several plant species. Blasko et al. (1988) reported that repeated sequence of Oenothera was recognized in an unsigned open reading frame of the inverted region. In the two European Alnus species (King and Ferris, 2000) and Italian populations of Orchis palustris (Cafasso et al., 2001), minisatellites were found in an intergenic spacer and an intron, respectively. Isoda et al. (2000) reported a tandem repeat in Abies. Filizi and Koc (2012) reported that all types of repeat motif of SSR (mono-, di-, tri-, tetra-and pentanucleotide) were detected in genus Olea except hexanucleotide motifs. In this study, minisatellites were revealed in the three non-coding regions.

The four non-coding regions of cpDNA used in this study revealed a mini- and four microsatellites. The trn $\mathrm{L}$ intron possessed two minisatellites and a microsatellite, and the other two regions had only microsatellite, respectively. Most of the SSRs were singlebase repeats. Mini- and microsatellites were also recognized in cpDNA of Douglas-fir (Hipkins et al., 1995). Powell et al. (1995) demonstrated that chloroplast microsatellites are predominantly mononucleotide repeats.

Mini- and microsatellites revealed in this study could be used for identifying species. The minisatellite in the $\operatorname{trn} \mathrm{L}$ intron could distinguish $A$. aulacocarpa and $A$. crassicarpa from $A$. mangium. However, since A. auriculiformis possessed the polymorphism within species, the minisatellite could not be used for distinguishing A. auriculiformis from the other species. The two microsatellites could distinguish the two groups of Acacia species. Thus, mini- and microsatellites recognized in this study can be used for species identification of the four Acacia species. Morand-Prieur et al. (2002) reported that Fraxinus excelsior could be distinguished from F. angustifolia by cpDNA microsatellite.

\section{Distribution of cpDNA haplotypes in the four Acacia species}

Ten cpDNA haplotypes based on the substitution and indel (mini- and microsatellite) were recognized. Half of them (A - E) were observed in A. aulacocarpa and $A$. crassicarpa, and the other half in $A$. auriculiformis and $A$. mangium. These two groups had totally different cpDNA haplotypes.

Of the four species, only A. mangium revealed no haplotype variation within species. The other three species showed a geographically different distribution of cpDNA haplotypes. By the haplotype distribution, $A$. aulacocarpa and $A$. auriculiformis show the similar geographic separation as has been reported previously. Thomson (1994) and McGranahan et al. (1997) distinguished A. aulacocarpa into five distinct groups, that is, New Guinea, Cairns, Northern Territory/ 
Western Australia, North Queensland and South Queensland/North New South Wales. In this study, the six samples were distinguished into three groups, New Guinea, North Queensland and South Queensland. No samples from Northern Territory and Cairns were used in this study. In case of $A$. auriculiformis, the six samples were separated into three areas, New Guinea, Northern Territory and Queensland. This result is similar to Wickneswary and Norwati (1993). The genetical separation of $A$. crassicarpa has not been reported. However, this study showed that New Guinea and Queensland could be separated based on the sequence of four non-coding regions of cpDNA.

\section{Application of the result for the breeding program and the future study}

Many experiments using cpDNA markers have been reported. Microsatellite markers have become popular for many genetic studies because they are highly polymorphic in many species. Chloroplast microsatellite has been used for analyzing genetic diversity in genus Olea (Filizi and Koc, 2012), maritime pine (Ribeiro et al., 2001), Solanaceous plants (Bryan et al., 1999), Pinus radiata (Cato and Richardson, 1996), soybean (Xu et al., 2002) and Sorbus L. (King and Ferris, 2000). Studies of the inheritance using chloroplast microsatellite also have been reported in Fraxinus (Morand-Prieur et al., 2002), Abies alba (Ziegenhagen et al., 1998) and Helianthus annuus (Wills et al., 2005). Stoehr et al. (1998) and Fernandes et al. (2008) applied cpDNA marker to the seed orchard management.

In this study, base substitutions, miniand microsatellites have been recognized in non-coding regions of cpDNA. This information can be used to develop the cpDNA markers for the Acacia species. Bukhari et al. (1999) reported phylogenetic relationships of several Acacia species based on the chloroplast RFLP data. Although chloroplast RFLPs are more variable than most of the phenotypic characteristics, RFLPs are time- and cost-consuming, and need a large quantity of DNA. Genetic analysis using the polymerase chain reaction (PCR) is less time consuming, technically simple and needs small amount of DNA. Microsatellites have become the available markers for many genetic studies because they are easy to analyze by using PCR and polyacrylamide gel electrophoresis (Powel et al., 1995). By developing the PCR-based markers based on the sequence information, many experiments can be carried out for the Acacia improvement programs.

\section{Conclusion}

Many information could be obtained by developing the PCR-based markers based on the sequence information. Not only substitutions, but also mini- and microsatellite could be detected. This information can be used for carrying out another experiment for conservation and tree improvement programs. In this study, for example, substutitions and mini-and microsatellite detected in four non-coding regions of chloroplast DNA can distinguished ten haplotypes. The haplotypes can be used for identifying 2 groups of four Acacia species. In future, many experiment using the substitutions, mini- and microsatellite and haplotypes can be carried out to support conservation and breeding programs of the Acacia species.

\section{References}

Balodis, V. and N. B. Clark., 1998. Tropical acacias - the new pulpwood. APPITA ASIA, 51, 179-181.

Bryan, G. J., J. McNicol, G. Ramsay, and R. C. Meyer., 1999. Polymorphic simple sequence repeat markers in chloroplast genomes of Solanaceous plants. Theoretical and Applied Genetics, 99, 859-867.

Bukhari, Y. M., K. Koivu, and P. M. A. Tigerstedt., 1999. Phylogenetic analysis of Acacia (Mimosaceae) as revealed from chloroplast RFLP data. Theoretical and Applied Genetics, 98, 291-298. 
Butcher, P. A. and G. F. Moran., 2000. Genetic linkage mapping in Acacia mangium. 2. Development of an integrated map from two outbred pedigrees using RFLP and microsatellite loci. Theoretical and Applied Genetics, 101, 594-605.

Butcher, P. A., G. F. Moran, H. D. and Perkins., 1998. RFLP diversity in the nuclear genome of Acacia mangium. Heredity, 81, 205-213.

Cafasso, D., G. Pellegrino, A. Musacchio, A. Widmer and M. F. Wojciechowski., 2001. Characterization of a minisatellite repeat locus in the chloroplast genome of Orchis palustris (Orchidaceae). Current Genetics, 39, 394-398.

Cato, S. A. and T. E. Richardson., 1996. Inter- and intraspecific polymorphism at chloroplastSSR loci and the inheritance of plastids in Pinus radiata D. Don. Theoretical and Applied Genetics, 93, 587-592.

Dumolin-Lapègue, S., M.-H. Pemonge, L. Gielly, P. Taberlet, and J. Petit., 1999. Amplification of oak DNA from ancient and modern wood. Molecular Ecology, 8, 2137-2140.

Fernandes, L., M. Rocheta, J. Cordeiro, S. Pereira, S. Gerber, M. M. Oliveira and M. M. Ribeiro., 2008. Genetic variation, mating patterns and gene flow in a Pinus pinaster Aiton clonal seed orchard. Ann. For. Sci., 65, 706p1-706p10. DOI: 10.1051/ forest:2008049.

Filizi, E. and I. Koc., 2012. In Silico chloroplast SSRs mining of Olea species. Biodiversitas, 13, 114-117.

Fujii, N., K. Ueda, Y. Watano and T. Shimizu., 1997. Intraspecific sequence variation of chloroplast DNA in Pedicularis chamissonis Steven (Scrophulariaceae) and geographic structuring of the Japanese "Alpine" plants. Journal of Plant Research, 110, 195207.

Hipkins, V. D., K. A. Marshall, D. B. Neale, W. H. Rottman and S. H. Strauss., 1995. A mutation hotspot in the chloroplast genome of a conifer (Douglas-fir: Pseudotsuga) is caused by variability in the number of direct repeats derived from a partially duplicated tRNA gene. Current Genetics, 27, 572-579.

Isoda, K., S. Shiraishi and H. Kisanuki., 2000. Classifying Abies species (Pinaceae) based on the sequence variation of a tandemly repeated array found in the chloroplast DNA $\operatorname{trn} \mathrm{L}$ and $\operatorname{trn} \mathrm{F}$ intergenic spacer. Silvae Genetica, 49, 161-165.

Khasa, P. D., W. M. Cheliak and J. Bousquet., 1993. Mating system of Racosperma auriculiforme in a seed production area in Zaire. Canadian Journal of Botany, 71, 779-785.

Khasa, P. D., W. M. Cheliak and J. Bousquet., 1994. Genetic variation in 26 populations of Racosperma auriculiforme and Racosperma mangium using allozymes. Canadian Journal of Forest Research, 24, 1123-1132.

King, R. A. and C. Ferris., 2000. Chloroplast DNA and nuclear DNA variation in the sympatric alder species, Alnus cordata (Lois.) Duby and A. glutinosa (L.). Gaertn. Biological Journal of the Linnean Society, 70, 147-160.

McGranahan, M., J. C. Bell, G. F. Moran and M. Slee., 1997. High genetic divergence between geographic regions in the highly outcrossing species Acacia aulacocarpa (Cunn. ex Benth.). Forest Genetics, 4, 1-13.

Moran, G. F., O. Muona and J. C. Bell., 1989. Acacia mangium: A tropical forest tree of the coastal lowlands with low genetic diversity. Evolution, 43, 231-235.

Morand-Prieur, M. E., F. Vedel, C. Raquin, S. Brachet, D. Sihachark and N. FrascariaLacoste., 2002. Maternal inheritance of a chloroplast microsatellite marker in controlled hybrids between Fraxinus excelsior and Fraxinus angustifolia. Molecular Ecology, 11, 613-617.

Murphy, D. J., F. Udovicic and P. Y. Ladiges., 2000. Phylogenetic analysis of Australian Acacia (Leguminosae: Mimosoideae) by using sequence variations of an intron and two intergenic spacers of chloroplast DNA. Australian Systematic Botany, 13, 745-754. 
Ohsako, T. and O. Ohnishi., 2000. Intraand interspecific phylogeny of wild Fagopyrum (Polygonaceae) species based on nucleotide sequences of noncoding regions in chloroplast DNA. American Journal of Botany, 84, 573-582.

Olmstead, R. G. and J. D. Palmer., 1994. Chloroplast DNA systematics - A review of methods and data-analysis. American Journal of Botany, 81, 1205-1224.

Powell, W., M. Morgante, R. McDevitt, G. G. Vendramin and J. A. Rafalski., 1995. Polymorphic simple sequence repeat regions in chloroplast genomes: Applications to the population genetics of pines. Proceedings of the National Academy of Sciences of the United States of America, 92, 7759-7763.

Provan, J., G. Corbett, R. Waugh, J. W. McNicol, M. Morgante and W. Powell., 1996. DNA fingerprints of rice (Oryza sativa) obtained from hypervariable chloroplast simple sequence repeats. Proceedings of the Royal Society of London Series B-Biological Sciences, 263, 12751281.

Ribeiro, M. M., C. Plomion, R. Petit, G. G. Vendramin and A. E. Scmidt., 2001. Variation in chloroplast single-sequence repeats in Portuguese maritime pine (Pinus pinaster Ait.). Theoretical and Applied Genetics, 102, 97-103.

Stoehr, M. U. and C. H. Newton., 2002. Evaluation of mating dynamics in lodgepole pine seed orchard using chloroplast DNA markers. Canadian Journal of Forest Research, 28, 187-195.

Stoehr, M. U., B. L. Orvar, T. M. Vo, J. R. Gawley, J. E. Webber and C. H. Newton., 1998. Application of a chloroplast DNA marker in seed orchard management evaluations of Douglas-fir. Canadian Journal of Forest Research, 28, 187-195.

Thomson, L.-A. J. (1994) Acacia aulacocarpa, A. cincinnata, $A$. crassicarpa and $A$. wetarensis: an annotated bibliography. Division of Forestry, Australian Tree Seed Centre, Canberra. 131pp.
Watanabe, A., H. Maeda and S. Shiraishi., 1997. A simple identification of chloroplast genome types between Pinus densiflora Sieb. et Zucc. and P. thunbergii Parl. using PCR-SSCP Analysis. Journal of Japanese Forest Science, 79, 155-156.

Wickneswary, R. and M. Norwati., 1993. Genetic diversity of natural populations of Acacia auriculiformis. Australian Journal of Botany, 41, 65-77.

Widyatmoko, AYPBC. and S. Shiraishi., 2010. Study on Genetic Variation and Relationship among Four Acacia Species using RAPD and SSCP Markers. Journal of Forestry Research, 7,125-143.

Widyatmoko, AYPBC. and S. Shiraishi., 2011. Sequence Polymorphisms of Four Chloroplast Genes in Four Acacia Species. Journal of Forestry Research, 8,79-89.

Wills, D. M., M. L. Hester, A. Liu and J. M. Burke., 2005. Chloroplast SSR polymorphisms in the Compositae and the mode of organellar inheritance in Helianthus annuus. Theoretical and Applied Genetics, 110, 941-947.

Xu, D. H., J. Abe, J. Y. Gai and Y. Shimamoto., 2002. Diversity of chloroplast DNA SSRs in wild and cultivated soybeans: evidence for multiple origins of cultivated soybean. Theoretical and Applied Genetics, 105, 645653.

Xu, D. H., J. Abe, M. Sakai, A. Kanazawa and Y. Shimamoto., 2000. Sequence variation of non-coding regions of chloroplast DNA of soybean and related wild species and its implications for the evolution of different chloroplast haplotypes. Theoretical and Applied Genetics, 101, 724-732.

Ziegenhagen, B., F. Schloz, A. Madaghiele and G. G. Vendramin., 1998. Chloroplast microsatellites as markers for paternity analysis in Abies alba. Canadian Journal of Forest Research, 28, 317-321. 